\title{
Awareness of farm workers regarding health problems and use of protective clothing during pesticide application
}

Saroj Yadav*
Department of Textile and Apparel Designing, I.C. College of Home Science, Chaudhary
Charan Singh Haryana Agricultural University, Hisar (Haryana), India

Geeta Gaba

Department of Textile and Apparel Designing, I.C. College of Home Science, Chaudhary Charan Singh Haryana Agricultural University, Hisar (Haryana), India

*Corresponding author. E-mail: saroj16.yadav@gmail.com

\section{Abstract}

Pesticides are widely used in agricultural production to prevent or control pests, diseases, weeds, and other plant pathogens in an effort to reduce or eliminate yield losses of cotton crop and maintain high product quality. Because of high biological activity, and in some cases, long persistence in the environment, pesticides (pyrethroids, carbamate, oganophosphate, organochlorines) may cause harmful effects to human health and to the environment. Occupational exposure to pesticides often occurs in the case of agricultural workers in open fields and greenhouses. Farmers who perform spray activity are routinely exposed to high levels of pesticides (Monocarbamide dihydrogen sulfate, pyrethroids and carbamates), than the other farm workers such as pesticide loader, evaluator. The dermal and inhalation routes of entry are typically the most common routes of farmers' exposure to pesticides. Farmers' exposure to pesticides can be reduced through less use of pesticides and use of the appropriate protective clothing and equipments in all stages of pesticide handling. The present study was conductedon 270 respondents from all nine blocks of Hisar district of Haryana state to create awareness amongst them regarding health problems and use of protective clothing during pesticide application.An educational package in the form of Video CD and Leaflet was used. Pamphlets were distributed; lecture-cum-demonstrations and film shows were organized. Protective clothing and accessories were also exhibited for better impact. It was recorded that respondents succeeded in acquiring awareness at post exposure level, through print and electronic media for each message viz. breathing problems $(23.3 \%)$, eyes related problems $(100 \%)$, skin allergy $(43.3 \%)$, headache $(60.3 \%)$, fainting due to inhalation of pesticide $(64.33 \%)$ and stomach related problems $(23.56 \%)$.

Keywords: Awareness, Farmers, Health problems, Pesticides, Protective clothing

\section{Article Info}

DOI:10.31018/jans.v10i2.1732

Received: November 28, 2017

Revised: January 25, 2018

Accepted: March 17, 2018

How to Cite

Yadav, S. and Gaba, G. (2018). Awareness of farmers workers regarding health problems and use of protective clothing during pesticide application. Journal of Applied and Natural Science, 10(2): $540-543$

\section{INTRODUCTION}

Pesticides are common chemicals used to eliminate a great variety of unwelcome living organisms, particularly in agriculture. Pesticides are widely used in agricultural production to prevent or control pests, diseases, weeds, and other plant pathogens in an effort to reduce or eliminate yield losses and maintain high product quality. Because of high biological activity, and, in some cases, long persistence in the environment, pesticides may cause harmful effects to human health and to the environment. Although pesticides are developed through very strict regulation processes to function with reasonable certainty and minimal impact on human health and the environment, serious concerns have been raised about health risks resulting from occupational exposure and from residues in food and drinking water.
Exposure of the general population to pesticides occurs primarily through eating food and drinking water contaminated with pesticide residues, whereas substantial exposure can also occur in or around the home. Occupational exposure to pesticides often occurs in the case of agricultural workers in open fields and greenhouses, workers in the pesticide industry.

Pesticides are hazardous by design as the chemicals are manufactured with the aim of killing, repelling or inhibiting the growth of living organisms by impairing biological processes essential for the maintenance of life. In many cases pesticides not only affect the physiology of the pest species they are intended to control, but also impact upon the well-being of human adults and children. This phenomenon is particularly associated with insecticides, many of which are designed to interfere with biological systems common throughout much 
of the animal kingdom, such as the nervous and reproductive systems. Pesticides may cause respiratory, immunological, neurological and developmental effect as well as reproductive dysfunction and cancer. The magnitude of effect may be mild or severe and onset may be immediate or delayed. The resulting condition may be short or long term, reversible or irreversible.

Farmers' exposure mainly occurs during the preparation and application of the pesticide spray solutions and during the cleaning-up of spraying equipment (Damalas and Koutroubas, 2016).

Use of appropriate PPE, such as coveralls, and the adoption of other protective measures and good personal hygiene such as showering, not smoking, eating or drinking while handling pesticides are considered good practices to reduce occupational pesticide exposure. An increase in the use of protective measures decreases the probability of poisoning by $44 \%$ to $80 \%$, whereas lack of PPE use increases the potential for dermal and respiratory exposure to pesticides. The study also revealed that there are low levels of adoption of protective behaviors to reduce occupational exposure to pesticides. The majority of farmers fail to use any PPE, while fewer than $5 \%$ use all the recommended equipment (Keifer, 2000).

Protective clothing is specially designed to shield or guard parts of the wearer which are exposed to machines/their moving parts or are exposed to toxic and harmful chemical substances i.e. gases, liquids and particles etc leading to respiratory problems, skin ailments and eye problems. Protective garments must provide protection to the wearer without having any adverse effect on their work efficiency (Wenner, 2003). The main barrier in adopting the protective clothing is the discomfort caused during hot and humid climate, lack of proper use of protective clothing and cost of protective clothing that is why they avoid the use of personal protective clothing. There is need to create awareness among the farm workers about the use of protective clothing and provide the protective clothing at affordable price so that that they may adopt it. Therefore, keeping this in mind a study was conducted on creating awareness among farm workers regarding health problems and use of protective clothing during pesticide application was conducted.

\section{MATERIALS AND METHODS}

Selection of villages: Total nine blocks (Hisar-I, Hisar-II, Adampur, Agroha, Barwala, Hansi-I, HansiII, Narnaund, Uklana) were selected from Hisar district. One village was randomly selected from each block on the basis of easy accessibility to villages where cotton is mainly grown as a crop. Thus nine villages (Chaurdhariwali, Khasa Mahajanan, Behbalpur, Dhani Kutubpur, Jeetpura, Shikarpur, Devan, Nara, Mughalpura) were taken for study.

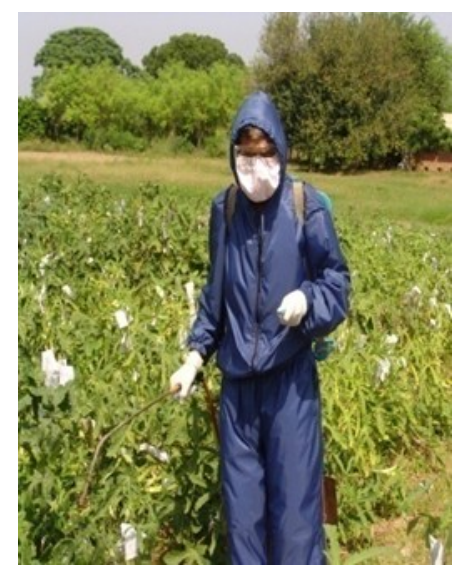

Fig. 1. Dress for pesticide applicators.

Selection of respondents: The farm workers who were engaged in spraying of pesticides were selected for study. Thirty respondents from each village was randomly selected, thus total 270 respondents were selected.

Creating awareness: To create awareness regarding occupational health problems and protective clothing an educational package in the form of pamphlets and video film was used. Pamphlets were distributed; lecture-cum-demonstrations and film shows were organized. The duration of video was 20 minutes. The use of Protective clothing was demonstrated for better impact.

Awareness assessment: To assess the change in awareness, interview schedule was administered on the respondents before and after exposure to media. The difference between pre exposure and post exposure scores were computed separately. The difference between pre and post exposure scores so obtained was taken as change in awareness. For measurement of significance of change in awareness paired 't' test was applied.

Acceptability assessment of protective clothing: Developed protective clothing i.e. Jacket with hood and Pyjama of water proof fabric (having lining of cotton hosiery fabric), beak mask and pleated maskwere exhibited and wear trials were also conducted on the respondents in selected villages during the awareness campaign. For assessment of acceptability of developed protective clothing, formulated statements were assessed on three point rating scale i.e. agree, somewhat agree and disagree scoring 2,1 and 0, respectively. Acceptability score was calculated by summing scores assigned to each statement. Total acceptability scores were divided into three categories i.e high, medium and low.

\section{RESULTS AND DISCUSSION}

Change in awareness of the respondents regarding health problems during pesticide application: Data related to change in awareness of the respondents from all the nine blocks of 


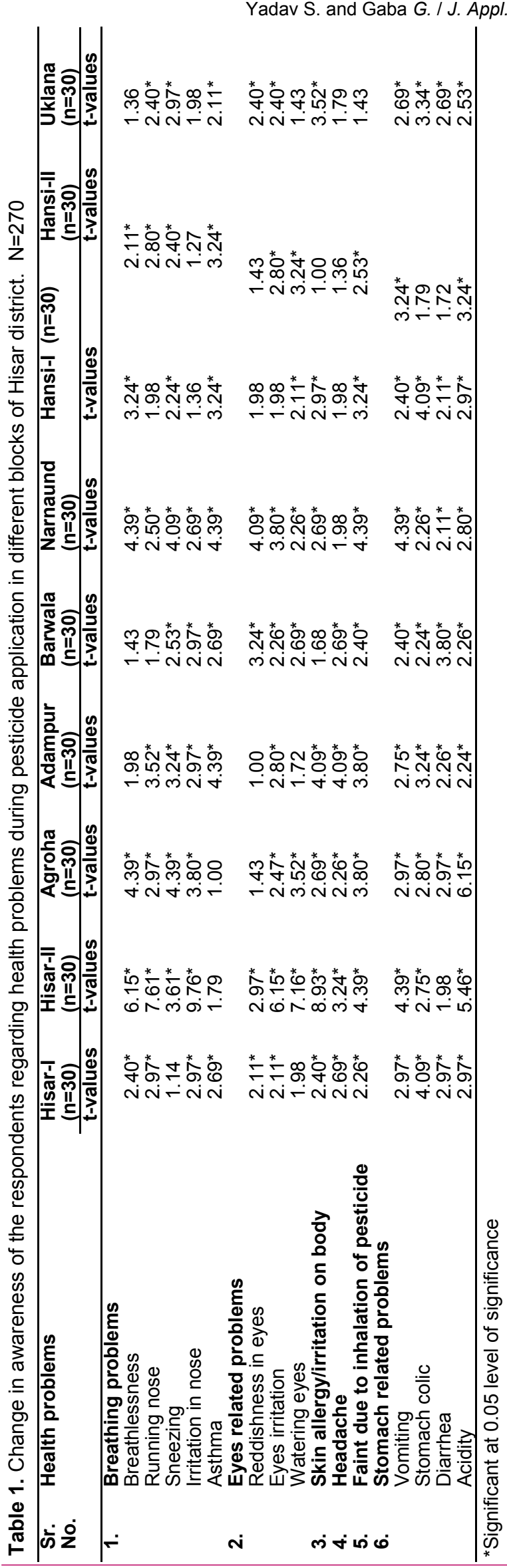

Table 2. Acceptability of protective clothing/ accessories. $n=270$

\begin{tabular}{|c|c|c|}
\hline $\begin{array}{l}\text { S. } \\
\text { N. }\end{array}$ & Statements & $\begin{array}{c}\text { Weighted } \\
\text { Mean Score }\end{array}$ \\
\hline 1. & $\begin{array}{l}\text { Protective clothing are easy to } \\
\text { wear and remove }\end{array}$ & 1.65 \\
\hline 2. & $\begin{array}{l}\text { Protective clothing does not } \\
\text { look awkward }\end{array}$ & 1.19 \\
\hline 3. & $\begin{array}{l}\text { Functional features/fasteners } \\
\text { used in garments do not } \\
\text { cause pinching }\end{array}$ & 1.70 \\
\hline 4. & $\begin{array}{l}\text { Protective clothing do not } \\
\text { have adverse effect on the } \\
\text { work efficiency }\end{array}$ & 1.80 \\
\hline 5. & $\begin{array}{l}\text { Protective clothing can be } \\
\text { washed and maintained easily }\end{array}$ & 1.78 \\
\hline 6. & $\begin{array}{l}\text { Designs are so simple that } \\
\text { person good at stitching can } \\
\text { follow the design }\end{array}$ & 1.41 \\
\hline 7. & $\begin{array}{l}\text { It is worth spending extra } \\
\text { money on protective clothing }\end{array}$ & 1.59 \\
\hline 8. & $\begin{array}{l}\text { To prevent health hazards, } \\
\text { we should definitely use pro- } \\
\text { tective clothing }\end{array}$ & 1.83 \\
\hline 9. & $\begin{array}{l}\text { I will suggest other fellows to } \\
\text { adopt protective clothing }\end{array}$ & 1.61 \\
\hline 10. & $\begin{array}{l}\text { The garments are not com- } \\
\text { fortable due to functional fea- } \\
\text { tures }\end{array}$ & 0.20 \\
\hline 11. & $\begin{array}{l}\text { The functional features in } \\
\text { protective clothes cause hin- } \\
\text { drance at work place }\end{array}$ & 0.24 \\
\hline 12. & $\begin{array}{l}\text { The washing and mainte- } \\
\text { nance of protective clothing is } \\
\text { difficult }\end{array}$ & 0.25 \\
\hline 13. & $\begin{array}{l}\text { Protective clothing should not } \\
\text { be worn as these might en- } \\
\text { tangled while working }\end{array}$ & 0.20 \\
\hline 14. & $\begin{array}{l}\text { These garment should not be } \\
\text { recommended because they } \\
\text { are not useful }\end{array}$ & 0.20 \\
\hline
\end{tabular}

Acceptability Score: High: 1.34 - 2.0,Medium: 0.67 1.33, Low: $0-0.66$

Hisar district for all the messages of health problems have been incorporated in Table 1. The data pertaining to attributes of 'Breathing problem' 't'values explained that awareness level of respondents of Hisar-II block was maximum in almost all the parameters viz., 'Breathlessness' $(t=6.15)$, 'Running nose' ( $t=7.61)$, 'Sneezing' $(t=3.61)$, 'Irritation in nose' ( $\mathrm{t}=9.76)$, 'Eyes irritation' ( $\mathrm{t}=6.15)$, 'Watering eyes' $(\mathrm{t}=$ 7.16) and 'Skin allergy' $(\mathrm{t}=8.93)$.

Data related to the 'Fainting due to inhalation of pesticide' and 'Vomiting' in terms of change in awareness, 't'-values indicate that change in awareness by the respondents of Hisar-II and Barwala blocks was adjudged to be maximum $(\mathrm{t}=4.39$ each), whereas in case of 'Asthma' maximum change in awareness was found for respondents of Adampur and Narnaund blocks 
$(\mathrm{t}=4.39)$. For Reddishness in eyes' the respondents of Narnaund block shown maximum change in awareness $(t=4.09)$ followed by respondents of Barwala block $(\mathrm{t}=3.24)$.

The data concerning change in awareness about 'Headache' $t$ '- values indicate that change in awareness was maximum in respondents of Adampur block $(\mathrm{t}=4.09)$ followed by respondents of Hisar-II ( $\mathrm{t}=3.24)$, Hisar-I and Agroha blocks $(t=2.69$ each $)$.

Regarding 'Stomach related problems' 't'- values indicate that awareness level of respondents of Hisar-I and Hansi-I was maximum in case of stomach colic ( $\mathrm{t}=4.09 \mathrm{each})$, for 'Diarrhea' the change in awareness was found maximum for respondents of Barwala block $(t=3.80)$ and for 'Acidity' it was found maximum for respondents of Agroha block ( $t=6.15)$ after exposure to media sources. The results of the study are in line with Kumari (2013) who reported that respondents from Sirsa district of Haryana gained knowledge regarding protective clothing after exposure to media sources.

Acceptability of protective clothing by farm workers: Data presented in Table 2 reveal that protective clothing/ accessories were found to be acceptable to maximum number of respondents involved in pesticide application. The respondents reported that though the protective clothing took some extra time while wearing and removing (WMS 1.65) even then majority of the respondents opined that to prevent health hazards, one should definitely use protective clothing (WMS 1.83) and also the protective clothing did not have adverse effect on work efficiency (WMS 1.80). The functional features/fasteners used in garments did not cause pinching (WMS 1.70), protective clothing can be washed and maintained easily (WMS 1.78). The respondents strongly agreed to suggest other fellows to adopt protective clothing (WMS 1.61) and found worth to spend extra money on protective clothing (WMS 1.59)

Only few respondent agreed with the statement that 'the washing and maintenance of protective clothing is difficult (WMS 0.25)','The functional features in protective clothes cause hindrance at work place' (WMS 0.24), 'The garments are not comfortable due to functional features'(WMS 0.20 ), 'These garments should not be recom- mended because these are not useful; (WMS 0.20 ) and 'Protective clothing should not be worn as these might entangle while working'(WMS $0.20)$. Hence it was concluded that the majority of respondents showed the positive attitude towards the protective clothing. Results of the study are found in line with the Makkar (2005) who highlighted that the developed protective clothing were well accepted by the respondents as were found effective in restricting dermal absorption of pesticides. Protective clothing has no adverse effect on work efficiency, did not cause pinching.

\section{Conclusion}

Results of this study reported that majority of respondents (1.65) accepted that protective clothing is easy to wear and remove, 1.83 respondent agreed that to prevent health hazards, we should definitely use protective clothing. Majority of the respondent responded in favor of use of protective clothing while using pesticides. To increase farmers' knowledge about pesticide and limit the hazards associated with pesticides, it is recommended that priority should be given to developing and implementing pesticide safety educational programs for farmers.

\section{REFERENCES}

Damalas, C.A. and Koutroubas, S. D. (2016). Farmers' Exposure to Pesticides: Toxicity, Types and Ways of Prevention. Toxics, 4 (1).

Damalas, C.A. and Eleftherohorinos, I. G. (2011). Pesticide Exposure, Safety Issues, and Risk Assessment Indicators. International Journal of Environmental Research and Public health, 8(5): 1402-1419.

Kumari, P. (2013). Educational Package on Protective Clothing for Farm Workers. Unpublished Ph.D. Thesis, CCS Haryana Agricultural University, Hisar, Haryana.

Makkar, P. (2005). Functional Clothing for Farm Workers. Unpublished M.Sc. Thesis, CCS Haryana Agricultural University, Hisar, Haryana.

Wenner, M. and Arias, D (2003). Urban Agriculture Practices and Health Problems among Farmers Operating on a University Campus in Kumasi, Ghana. http://factsreports.revues.org/451.

Keifer M.C. (2016). Effectiveness of interventions in reducing pesticide overexposure and poisonings. Am. J. Prev. Med. 2000;18:80-89. doi: 10.1016/S0749-3797(00)00144-6. 